\title{
Equity Risk Premium Puzzle: Evidence from Indonesia and Sri Lanka
}

\section{Prabath S. Morawakage, Pulukkuttige D. Nimal \& Duminda Kuruppuarachchi}

To cite this article: Prabath S. Morawakage, Pulukkuttige D. Nimal \& Duminda Kuruppuarachchi (2018): Equity Risk Premium Puzzle: Evidence from Indonesia and Sri Lanka, Bulletin of Indonesian Economic Studies, DOI: 10.1080/00074918.2018.1529406

To link to this article: https://doi.org/10.1080/00074918.2018.1529406

Accepted author version posted online: 09 Oct 2018.

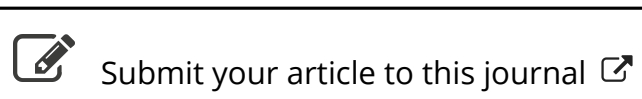

Џ Article views: 78

View Crossmark data ¿ 
Publisher: Taylor \& Francis \& ANU Indonesia Project

Journal: Bulletin of Indonesian Economic Studies

DOI: $10.1080 / 00074918.2018 .1529406$

Check for updates

Equity Risk Premium Puzzle: Evidence from Indonesia and Sri Lanka

\author{
Prabath S. Morawakage \\ Department of Finance \\ University of Kelaniya, \\ Kelaniya, Sri Lanka \\ Pulukkuttige D. Nimal \\ Department of Finance \\ University of Sri Jayewardenepura \\ Nugegoda, Sri Lanka \\ Duminda Kuruppuarachchi \\ Department of Accountancy and Finance \\ University of Otago \\ Dunedin \\ New Zealand
}

\title{
ABSTRACT
}

This paper investigates the equity risk premium puzzle in the stock markets of Indonesia and

Sri Lanka with the purpose of identifying the relationship between the volatility of excess returns and equity risk premium. Asymmetric impact of negative shocks on the equity risk premium is also examined using Threshold and Exponential GARCH-M models. We analyse the excess returns data of Indonesian and Sri Lankan stock markets from 2004 to 2013 in this study and we find that the impact of the conditional volatility of excess returns on risk premium is not significant in both countries. Instead, we find an impact from negative return shocks on the equity risk premium only in Sri Lanka. Therefore, we conclude that investors are not rewarded for the conditional volatility of excess returns in these two markets while Sri Lankan investors are compensated for the risk due to negative shocks.

Keywords: emerging markets, equity risk premium, GARCH-M, negative shocks 
JEL Classification: G1, C5, F0

\section{INTRODUCTION}

Stock market volatility has become a focal point of many research studies since "volatility itself is a puzzle" as mentioned by Wang and Ma (2013). Estimating volatility and analysing its relationship with equity risk premium (ERP) have become research areas in Finance.

Capital Asset Pricing Models (CAPM) in Sharpe (1964), Lintner (1965) and Black (1976) suggest a positive liner relationship between the risk or the volatility and expected returns of securities.

ERP has attracted the attention in asset pricing literature over a long period of time since its significance in determining the expected return of investments. Mehra and Prescott (1985) provide evidence for the ERP by introducing the ERP puzzle. They have proved that the historical ERP is an order of magnitude greater than that can be rationalized using the USA data gathered for the period from 1889 to 1978 . However, studies carried out using relatively recent data of the USA market find contradictory results to the above-mentioned ERP puzzle (Turner, Startz, and Nelson 1989; Glosten, Jagannathan, and Runkle 1993; and Nelson 1991; Kim, Morley, and Nelson 2004; Bekaert and Wu 2000). In contrast, a negative relationship or insignificant relationship between expected return and volatility has been evident.

ERP puzzle becomes further complicated since recent ERP does not compensate adequately for the risk due to the volatility of excess returns. Moreover, it is difficult to rationalize higher equity premiums in developed markets where the volatility is less than that of the emerging and frontier markets (Michelfelder and Pandya 2005). Damodaran (2003) points out that investors who invest in emerging markets require an additional risk premium called Country Risk Premium (CPR) because of higher volatility of those markets. 
Volatility of the emerging and frontier markets is further deepened by the leverage effect or negative shocks. Black (1976) finds that there is a leverage impact on the equity return series of the USA market, suggesting that a negative return would create more volatility than a positive return with the same magnitude, i.e., a negative information surprise may have a different impact than a positive information surprise. This has been explained by Glosten, Jagannathan, and Runkle (1993); Zakoian and Rabemananjara (1993) by introducing the GJR-GARCH and TGARCH models respectively. Studies carried out in India, Bangladesh, Sri Lanka and China using EGARCH and TGARCH models have revealed that there is a leverage effect on volatility (Banumathy and Azhagaiah 2015; Basher, Hassan, and Islam 2007; Jegajeevan 2010; Chen 2015).

Backus and Gregory (1993) document that the relationship between ERP and conditional volatility could be postive, negative or zero. A Sri Lankan study conducted by Kumara, Upananda, and Rajib (2014) also reveals an insignifiant relationship between volatility and ERP.

\subsection{Objectives of the Study}

The evidences produced above suggest that the relationship between equity premium and volatility has not been consistent over the time even in the same market as well as across different markets. Also, the relationship is not similar for positive and negative information shocks. Therefore, this study investigates the relationship between ERP and volatility of excess returns in stock markets of Indonesia (emerging) and Sri Lanka (frontier). This study also examines the impact of negative shocks on the ERP. Accordingly, the specific objectives

of the study are;

1. to test whether there is a relationship between volatility of excess returns and the ERP in Indonesia and Sri Lanka and 
2. to analyse whether the impact of volatility on ERP is affected by the negative shocks differently.

We use GARCH-M models to analyse daily Sri Lankan and Indonesian stock market data. We find there is no significant positive relationship between volatility (measured by conditional volatility) and the ERP in both markets which is not consistent with the rational asset pricing models, but consistent with Kumara, Upananda, and Rajib (2014). When the negative shocks of the markets are considered we find mixed relationships between risk and equity premium.

Although there are many studies which focus on volatility of the stock returns there is a dearth of research which tries to focus on the risk premiums in emerging markets. Furthermore, we introduce negative innovations to the mean equation to test whether the downside risk is compensated in the emerging markets. Thus, this study is novel and important in examining the volatility and the risk premium of emerging markets and frontier markets to understand contrasting features in those two markets which leads better decision making of investors. Overall this study opens a new line of research to investigate the volatility and risk premium of emerging markets vs. frontier markets.

The remainder of the paper proceeds as follows. Section Two describes the model that is used to analyse the relationship between risk and risk premium in Indonesian and Sri Lankan markets. Section Three discusses our empirical results and Section Four concludes.

\section{DATA AND METHODOLOGY}

\subsection{Sample and Data}


We collect data including ten years of daily Sri Lankan and Indonesian stock returns from 2004 to 2013 . The daily data employed in this study is drawn from the weighted equity market indices of two markets: namely, All Share Price Index of Sri Lanka and Indonesian Stock Index (Jakarta Composite Index). Sri Lanka Stock Exchange had 289 listed companies with a market capitalization of 20 billion US dollars at the end of 2013 and Indonesia Stock Exchange had 489 listed companies as of the first quarter 2014 with a combined market capitalization of around 360 billion US dollars. Daily risk-free rates are calculated converting the twelve months annual treasury bill rates to daily rates. Those daily treasury bill rates are deducted from the daily stock index returns in order to arrive at the daily excess returns from 2004 to 2013. The Sri Lankan stock market is selected as the frontier market, particularly due to the recent developments taking place to uplift the market conditions. Then, for the purpose of fare comparison, there should be a country from emerging markets.

According to the road map of Central Bank of Sri Lanka, country's per capita GDP will reach $\$ 4000$. At present, there are several countries that are closer to the per capita $\$ 4,000$. Indonesia is one of such countries which indicates capital market contribution to GDP as 50\% approximately. Sri Lanka also targets a 50\% contribution when the per capita income reaches $\$ 4000$ according to the Colombo Stock Exchange (CSE) roadmap 2013. Thus, Indonesia is desirable to be compared with Sri Lanka for the purpose of this study. Moreover, Indonesia is an emerging market according to the Bloomberg ranking. It is also within the top five emerging markets of Asia Pacific region.

\subsection{Research Model}

We mainly use GARCH-in-mean (GARCH-M) of Engle, Lilien and Robins (1987) which incorporates conditional volatility into the mean equation as illustrated in (1). This approach is widely used (see, e.g., Chan, Karolyi, and Stulz [1992]; Baillie and DeGennaro, 
[1990]; Bekaert and $\mathrm{Wu}$ [2000] among others) to analyse the time variant risk premium and the behaviour of return volatility in stock markets.

$R_{i t}=\beta_{0}+\beta_{1} R_{i t-n}+\delta_{1} \eta_{i t}+\varepsilon_{\mathrm{it}}$

Here, $R_{i t}$ is the daily risk premium ${ }^{1}$ and $\eta_{i t}$ is the conditional standard deviation of $R_{i t}$ for $i^{\text {th }}$ market at time $t . R_{i t-n}$ is the $n^{\text {th }}$ lag term of the $R_{i t}$ Also, $\varepsilon_{\mathrm{it}}$ is the random shock at time $t$ corresponding to the $i^{\text {th }}$ market. Furthermore, we incorporate the impact of past negative shocks on the risk premium in our mean equation to investigate the asymmetric effect of negative shocks on the risk premium as in equation (2) and (3).

$\mathrm{R}_{\mathrm{it}}=\beta_{0}+\beta_{1} R_{i t-n}+\delta_{2} j_{i t}\left|R_{i t-1}\right|+\varepsilon_{i t}$

$\mathrm{R}_{\mathrm{it}}=\beta_{0}+\beta_{1} R_{i t-n}+\delta_{3} j_{i t} \eta_{i t}+\varepsilon_{i t}$

Here, $j_{i t}=1$ if $R_{i t-1}<0$, and 0 otherwise. Since the risk is represented by the market conditional volatility, $\eta_{\mathrm{it}}$ and treated as an independent variable in equations (1), the underlying coefficient, $\delta_{1}$ acts as the risk aversion parameter. The mean equation in (2) directly captures the impact of negative shocks on the risk premium by $\delta_{2}$. Moreover, $\delta_{3}$ in equation (3) indicates how the impact of the conditional volatility on the risk premium is affected when a negative shock is present.

We model the underlying conditional variance of the risk premium using ThresholdGARCH model (TGARCH) proposed by Zakoian (1994) in equation (4) and EGARCH model proposed by Nelson (1991) in equation (5) in order to select the most appropriate

\footnotetext{
${ }^{1}$ Risk premium of the $i^{\text {th }}$ market at time $t\left(R_{i t}\right)$ is calculated using $R_{i t}=\left[\frac{\left[S P I_{i t}-S P I_{i t-1}\right]}{S P I_{i t-1}}\right] \times 100-r_{t}$ where, $S P I_{i t}$ is the stockprice index at time $t$ for the $i^{t h}$ market $r_{t}$ is the daily adjusted annual Treasury bill rate as a proxy for the risk free rate.
} 
specification in the presence of the asymmetric behaviour of conditional volatility due to negative shocks.

$\eta_{i t}^{2}=\alpha_{0}+\alpha_{1} \varepsilon_{i t-1}^{2}+\varnothing_{1} \eta_{i t-1}^{2}+\gamma \varepsilon_{t-1}^{2} \mathrm{I}_{\mathrm{t}-1}$

$\ln \eta_{i t}^{2}=\omega_{0}+\omega_{1} \ln \eta_{i t-1}^{2}++\lambda \frac{\varepsilon_{i t-1}}{\sqrt{\eta_{i t-1}}}+\omega_{2}\left[\frac{\left|\varepsilon_{i t-1}\right|}{\sqrt{\eta_{i t-1}}}-\sqrt{\frac{2}{\pi}}\right]$

Here, $I_{t-1}=1$ if $\varepsilon_{t-\mathbf{1}}<0$ and $I_{t-1}=0$ otherwise.

\subsection{Research Hypotheses}

In line with the objectives in this study, we test a series of hypotheses as follows. First, we examine the impact of the conditional volatility on the ERP using the model in equation (1). Thus, the risk aversion parameter, $\delta_{1}$ is tested as in hypothesis (1).

$\mathrm{H}_{10}: \delta_{1} \leq 0 \quad$ vs. $\quad \mathrm{H}_{11}: \delta_{1}>0$

Here, under the alternative hypothesis, $\mathrm{H}_{11}$ an investor is expected to be compensated for the risk arises due to the conditional volatility.

Hypothesis (2) tests whether the risk premium is affected by negative shocks occurred in the previous time period while hypothesis (3) tests the impact from the conditional volatility on the risk premium when a negative shock is present.

$\mathrm{H}_{20}: \delta_{2} \leq 0$ vs. $\mathrm{H}_{21}: \delta_{2}>0$

$\mathrm{H}_{30}: \delta_{3} \leq 0 \quad$ vs. $\quad \mathrm{H}_{31}: \delta_{3}>0$

In $\mathrm{H}_{21}$, it is expected that an investor is compensated due to a negative shock that happened in the previous time period while $\mathrm{H}_{31}$ expects a high compensation against the volatility risk when a negative shock is present. 


\section{RESULTS AND DISCUSSION}

Table 1 illustrates descriptive statistics of calculated risk premiums for Indonesian and Sri Lankan markets. Results corresponding to Jarque-Bera test for normality are also presented in Table 1.

Table 1: Descriptive Statistics

\begin{tabular}{lll}
\hline & Indonesia & Sri Lanka \\
\hline Mean & $0.07 \%$ & $0.05 \%$ \\
Median & $0.14 \%$ & $0.02 \%$ \\
Maximum & $7.90 \%$ & $7.55 \%$ \\
Minimum & $-10.41 \%$ & $-10.56 \%$ \\
Std. Dev. & $1.49 \%$ & $1.13 \%$ \\
Skewedness & -0.50 & -0.54 \\
Kurtosis & 8.90 & 14.50 \\
Observations & 2409 & 2409 \\
Jarque-Bera & $3596 * * *$ & $13380 * * *$ \\
ADF test statistic & $-43.985 * * *$ & $-40.195^{* * *}$ \\
ARCH LM test F-stat & $86.008^{* * *}$ & $14.065^{* * *}$ \\
\hline
\end{tabular}

Note: $* * *$ significant at $1 \%$ level

The average daily risk premiums are positive in both Sri Lanka $(0.046 \%)$ and Indonesia $(0.066 \%)$. Indonesian risk premium indicates relatively greater unconditional volatility than the Sri Lankan stock market according to the standard deviations. Both markets indicate negative skewedness and leptokurtosis during the sample period indicating deviations from the normal distribution. Jarque-Bera test also justifies the non-normality in risk premiums. The large kurtosis coefficients indicate leptokurtic risk premiums in both markets. Each risk premium series indicates stationarity according to the ADF test results in Table 1. Moreover, ARCH LM test indicates significant presence of Heteroscedasticity in both risk premium series and thus, time varying conditional volatility exists. 
Table 2 illustrates results of the basic model in equation (1) with GARCH $(1,1)$ variance specification which corresponds to a GARCH $(1,1)-\mathrm{M}$ model.

\section{Table 2: Results for GARCH (1,1)-M Model}

Model: GARCH (1,1)-M

$\mathrm{R}_{\text {it }}=\beta_{0}+\beta_{1} \mathrm{R}_{\mathrm{it}-\mathrm{n}}+\delta_{1} \eta_{\text {it }}$

$\eta_{i t}^{2}=\alpha_{0}+\alpha_{1} \varepsilon_{i t-1}^{2}+\emptyset_{1} \eta_{i t-1}^{2}$

\begin{tabular}{lll}
\hline Country & Coefficients & Estimate \\
\hline \multirow{4}{*}{ Indonesia } & $\delta_{1}$ & $0.086^{\mathrm{a}}$ \\
& $\beta_{1}$ & $0.063^{* *}$ \\
& $\alpha_{1}$ & $0.146^{* * *}$ \\
& $\varnothing_{1}$ & $0.823^{* * *}$ \\
\hline \multirow{5}{*}{ Sri Lanka } & $\delta_{1}$ & $0.027^{\mathrm{a}}$ \\
& $\beta_{1}$ & $0.223^{* * *}$ \\
& $\alpha_{1}$ & $0.282^{* * *}$ \\
& $\varnothing_{1}$ & $0.672^{* * *}$ \\
\hline
\end{tabular}

Note: $* * *$ Significant at $1 \%$ level, $* *$ Significant at $5 \%$ level

${ }^{a}$ One-tail p-value is computed

According to the results in Table 2, the null hypothesis (1) which implies that "There is no positive relationship between risk premium and the volatility" is tested. Insignificant $\delta_{1}$ in both countries does not justify the compensation for investors due to the market volatility either in Indonesia or Sri Lanka. However, the autoregressive coefficient in equation (1) and GARCH $(1,1)$ coefficients in equation (4) are significant for both countries. Moreover, Durbin Watson test statistics are close to two $(1.90,2.04)$ and Q statistics are insignificant for the models suggesting that serial correlations are absent ${ }^{2}$.

The seminal paper of Black (1976) discusses the leverage impact on stock markets has an asymmetric effect on volatility. He explains that a negative shock would create more

\footnotetext{
${ }^{2}$ These results are not reported here to conserve the space but available upon request.
} 
volatility than a postivie shock. The second objective of this study focuses on this phenomenon. If the volatility increases due to the negative shocks, investors need additional return for such excess volatility. Therefore, it is interesting to examine the impact from negative shocks on the excess returns.

Table 3 illustrates corresponding results using $\operatorname{GARCH}(1,1)$ variance model. It should be noted that, only the coefficient estimate of the asymmetric effect is presented in Table 3 as GARCH $(1,1)$ coefficients are already significant as illustrated in Table 2.

\section{Table 3: Asymmetric of negative shocks on volatility and Risk Premium}

Model:

$\mathrm{R}_{\mathrm{it}}=\beta_{0}+\beta_{1} R_{i t-1}+\delta_{1} \eta_{i t}$

EGARCH- $(1,1)$ Variance Equation

$\ln \eta_{i t}^{2}=\omega_{0}+\omega_{1} \ln \eta_{i t-1}^{2}++\lambda \frac{\varepsilon_{i t-1}}{\sqrt{\eta_{i t-1}}}+\omega_{2}\left[\frac{\left|\varepsilon_{i t-1}\right|}{\sqrt{\eta_{i t-1}}}-\sqrt{\frac{2}{\pi}}\right]$

TGARCH $(1,1)$ Variance Equation

$\eta_{i t}^{2}=\alpha_{0}+\alpha_{1} \varepsilon_{i t-1}^{2}+\emptyset_{1} \eta_{i t-1}^{2}+\gamma \varepsilon_{i t-1}^{2} I_{t-1}$ Where $I_{t-1}=1$ if $\varepsilon_{i t-1}<0$ and $=0$ otherwise

\begin{tabular}{|c|c|c|c|}
\hline Country & Model & Coefficients & Estimate \\
\hline \multirow{6}{*}{ Indonesia } & \multirow{3}{*}{ EGARCH } & $\delta_{1}$ & $0.089^{\mathrm{a}}$ \\
\hline & & $\beta_{1}$ & $0.078 * *$ \\
\hline & & $\lambda$ & $-0.121 * * *$ \\
\hline & \multirow{3}{*}{ TGARCH } & $\delta_{1}$ & $0.062^{\mathrm{a}}$ \\
\hline & & $\beta_{1}$ & $0.082 * *$ \\
\hline & & $\gamma_{1}$ & $0.193^{* * *}$ \\
\hline Country & Model & Coefficients & Estimate \\
\hline \multirow{6}{*}{ Sri Lanka } & \multirow{3}{*}{ EGARCH } & $\delta 1$ & $-0.009^{\mathrm{a}}$ \\
\hline & & $\beta 1$ & $0.221 * * *$ \\
\hline & & $\lambda$ & $-0.066 * *$ \\
\hline & \multirow{3}{*}{ TGARCH } & $\delta 1$ & $-0.002^{\mathrm{a}}$ \\
\hline & & $\beta 1$ & $0.227 * * *$ \\
\hline & & $\gamma 1$ & $0.172 * *$ \\
\hline
\end{tabular}

Note: $* * *$ Significant at $1 \%$ level, $* *$ Significant at $5 \%$ level

${ }^{a}$ One-tail p-value is computed

It is evident from Table 3 that both EGARCH-M and TGARCH-M models confirm the fact that a leverage effect exists in both markets suggesting that the negative shock to risk 
premium is likely to cause the volatility to rise by more than that of a positive shock of the same magnitude in consistent with the explanation in Black (1976). However, both EGARCH-M and TGARCH-M do not provide significant results to support the positive relationship between volatility and the risk premium which is similar to the results in Table 2 . Serial correlation is absent ${ }^{3}$ in these asymmetric models and better fit compared to GARCHM model. Next, we account asymmetric effects of the negative shocks on the risk premium $\left(\delta_{2}\right)$ and the impact of negative shocks on the relationship between volatility and the risk premium $\left(\delta_{3}\right)$ as in equation (2). We incorporate both TGARCH and EGARCH specifications to represent variance equations and corresponding results are illustrated in Table 4 . It should be noted that, we do not present GARCH $(1,1)$ coefficients in Table 4 as they are similarly significant to Table 2 .

Table 4 provides evidence for the absence of both asymmetric effects tested by hypotheses (2) and (3) for the Indonesian market. However, the Sri Lankan stock market exhibits a significant impact from the negative shocks that happened in the previous time period on the risk premium by rejecting the null hypothesis in (2).

\section{Table 4: Impact from Negative Shocks on Equity Risk Premium}

Model: $\quad \mathrm{R}_{\mathrm{it}}=\beta_{0}+\beta_{1} R_{i t-n}+\delta_{2} j_{i t}\left|R_{i t-1}\right|+\varepsilon_{i t} ; \mathrm{R}_{\mathrm{it}}=\beta_{0}+\beta_{1} R_{i t-1}+\delta_{3} j_{i t} \eta_{i t}+\varepsilon_{i t}$ $\eta_{i t}^{2}=\alpha_{0}+\alpha_{1} \varepsilon_{i t-1}^{2}+\varnothing_{1} \eta_{i t-1}^{2}$ Where $\mathrm{j}_{\mathrm{it}}=1$ if $R_{i t-1}<0$ and $\mathrm{j}_{\mathrm{it}}=0$ otherwise

\begin{tabular}{cll}
\hline \multirow{2}{*}{ Coefficients } & \multicolumn{2}{c}{ Estimate } \\
\cline { 2 - 3 } & Indonesia & Sri Lanka \\
\hline$\delta_{2}$ & 0.112 & $0.214^{* *}$ \\
$\delta_{3}$ & -0.015 & $-0.120^{* *}$ \\
\hline
\end{tabular}

Note: ** Significant at $5 \%$ level

${ }^{\text {a }}$ One-tail p-value is computed

\footnotetext{
${ }^{3}$ Corresponding results are available upon request.
} 
It is also evident that $\delta_{2}$ is positive $(0.214)$ and significant in the Sri Lankan market indicating a positive impact from the negative shock on the following period's risk premium. In contrast, $\delta_{3}$ becomes negative $(-0.120)$ and significant in the Sri Lankan market indicating that the magnitude of the relationship between conditional volatility and the risk premium drops due to a negative shock during the previous time period. Consistent with our finding, negative significant risk premiums against market volatilities in Malaysia and Taiwan are also evident in Michelfelder and Pandya (2005).

Moreover, there are some conflicting empirical findings. For example, Freneh, Schwert, and Stambaugh (1987); Campbell and Hentschel (1992); Bollerslev, Engle, and Wooldrige (1988); Harvey (1989) and Veronesi (1999) find that the relationship between volatility and expected return is positive. Kim, Morley, and Nelson (2004) conclude that there is a significant positive relationship between stock market volatility and the equity premium. However, Turner, Startz, and Nelson (1989); Glosten, Jagannathan, and Runkle (1993), and Nelson (1991) find that the relationship is negative. Bekaert and $\mathrm{Wu}(2000)$ also confirm the same negative relationship.

Michelfelder and Pandya (2005) state that the evidence in Koutmos, Lee, and Theodossiou (1994) is mixed (negative, positive, significant, not significant for ten nonemerging markets). Furthermore, risk premium estimations in their study do not provide any evidence of a consistent and significant risk premium for emerging or mature markets. This is consistent with the emerging markets results of Choudhry (1996) and the mature markets results of Koutmos, Lee, and Theodossiou (1994) as given by Michelfelder and Pandya (2005). We stress that irrespective of the market type as matured, emerging or frontier, the relationship between volatility and expected equity risk premium is not persuasive and conclusive. As such, Indonesia and Sri Lanka do not provide evidences infavour of ERP puzzle of Mehra and Prescott (1985) and Capial Asset Pricing Model of Sharpe (1964). 
We firmly believe that rational expectation is difficult to prove under these conditions. Evidences from Indonesia and Sri Lanka allow behavioral asset pricing theories since ERP is not a significant function of market volatility as explained by rational asset pricing theories.

\section{CONCLUSION}

This paper attempts 1) to test whether there is a positive impact from the conditional volatility of excess returns on the risk premium in Indonesia and Sri Lanka and 2) to analyse whether there is a different impact of volatility on risk premium when the negative shocks are present. Using daily returns of the Sri Lankan stock market and the Indonesian stock market from 2004 to 2013 we find that there is no relationship between the equity risk premium and conditional volatility in Indonesian and Sri Lankan stock markets. We employ both symmetric and asymmetric GARCH-M models to incorporate the asymmetric effect of negative shocks on the risk premium and conditional volatility. Although a direct relationship from the conditional volatility to the risk premium does not exists, the Sri Lankan stock market exhibits that a negative shock on the previous day tends to increase the premium on the following day. However, the same shock causes to reduce the strength of the relationship between conditional volatility and risk premium. The Indonesian market does not show such significant relationships. In contrast, leverage effects exist in both Indonesian and Sri Lankan markets which cause to increase market volatility due to negative shocks than positive shocks.

The classical Equity Risk Premum puzzle of Mehra and Prescott (1985)says that larger ERP can not be explained by a rational theoritical framwork. However, the problem here is a negative or a zero relationship between ERP and the conditional volatility suggesting that risk premium is not sufficient to compensate for the market volatility. Furthermore, ERP is not an increasing function of volatility or risk as asset pricing theories explain. Therefore ERP 
puzzle takes a new dimention in the selected markets as ERP is not sufficent to componsate for the market volatilty.

\section{REFERENCES}

Backus, David K., and Allan W. Gregory. 1993. "Theoretical Relations Between Risk Premiums And Conditional Variances". Journal Of Business \& Economic Statistics 11 (2): 177-185. doi:10.1080/07350015.1993.10509946.

Baillie, Richard T., and Ramon P. DeGennaro. 1990. "Stock Returns And Volatility". The Journal Of Financial And Quantitative Analysis 25 (2): 203. doi:10.2307/2330824.

Banumathy, Karunanithy, and Ramachandran Azhagaiah. 2015. "Modelling Stock Market Volatility:Evidence From India". Modelling Stock Market Volatility:Evidence From India. 13 (1): 27-42.

Basher, Syed A., M. Kabir Hassan, and Anisul M. Islam. 2007. "Time-Varying Volatility And Equity Returns In Bangladesh Stock Market". Applied Financial Economics 17 (17): 1393-1407. doi:10.1080/09603100600771034.

Bekaert, Geert, and Guojun Wu. 2000. "Asymmetric Volatility And Risk In Equity Markets". Review Of Financial Studies 13 (1): 1-42. doi:10.1093/rfs/13.1.1.

Black, Fisher. 1976. "Studies Of Stock Price Volatility Changes". In Meeting Of The Business And Economic Statistics Section, 177-181. Washington, D.C: American Statistical Association.

Bollerslev, Tim. 1986. "Generalized Autoregressive Conditional Heteroskedasticity". Journal Of Econometrics 31 (3): 307-327. doi:10.1016/0304-4076(86)90063-1. 
Bollerslev, Tim. 1987. "A Conditionally Heteroskedastic Time Series Model For Speculative Prices And Rates Of Return". The Review Of Economics And Statistics 69 (3): 542. doi:10.2307/1925546.

Bollerslev, Tim, Robert F. Engle, and Jeffrey M. Wooldridge. 1988. "A Capital Asset Pricing Model With Time-Varying Covariances". Journal Of Political Economy 96 (1): 116131. doi:10.1086/261527.

Brook, Chris. 2008. Introductory Econometrics For Finance. 3rd ed. Cambridge: Cambridge University Press.

Campbell, John Y., and Ludger Hentschel. 1992. "No News Is Good News". Journal Of Financial Economics 31 (3): 281-318. doi:10.1016/0304-405x(92)90037-x.

Campbell, John Y. 2014. "Empirical Asset Pricing: Eugene Fama, Lars Peter Hansen, And Robert Shiller". The Scandinavian Journal Of Economics 116 (3): 593-634. doi:10.1111/sjoe. 12070 .

Chan, K.C., G.Andrew Karolyi, and RenéM. Stulz. 1992. "Global Financial Markets And The Risk Premium On U.S. Equity". Journal Of Financial Economics 32 (2): 137-167. doi:10.1016/0304-405x(92)90016-q.

Chen, Menggen. 2015. "Risk-Return Tradeoff In Chinese Stock Markets: Some Recent Evidence". International Journal Of Emerging Markets 10 (3): 448-473. doi:10.1108/ijoem-06-2012-0058.

Choudhry, Taufiq. 1996. "Stock Market Volatility And The Crash Of 1987: Evidence From Six Emerging Markets". Journal Of International Money And Finance 15 (6): 969-981. doi:10.1016/s0261-5606(96)00036-8. 
Damodaran, Aswath. 2003. "Measuring Company Exposure To Country Risk: Theory And Practice". Journal Of Applied Finance 13 (2): 63-76.

Duan, Jin-Chuan, and Weiqi Zhang. 2014. "Forward-Looking Market Risk Premium". Management Science 60 (2): 521-538. doi:10.1287/mnsc.2013.1758.

Engle, Robert F. 1982. "Autoregressive Conditional Heteroscedasticity With Estimates Of The Variance Of United Kingdom Inflation". Econometrica 50 (4): 987-1007. doi:10.2307/1912773.

Engle, Robert F., David M. Lilien, and Russell P. Robins. 1987. "Estimating Time Varying Risk Premia In The Term Structure: The Arch-M Model". Econometrica 55 (2): 391407. doi:10.2307/1913242.

French, Kenneth R., G.William Schwert, and Robert F. Stambaugh. 1987. "Expected Stock Returns And Volatility". Journal Of Financial Economics 19 (1): 3-29. doi:10.1016/0304-405x(87)90026-2.

Glosten, Lawrence R., Ravi Jagannathan, and David E. Runkle. 1993. "On The Relation Between The Expected Value And The Volatility Of The Nominal Excess Return On Stocks". The Journal Of Finance 48 (5): 1779-1801. doi:10.2307/2329067.

Harvey, Campbell R. 1989. "Time-Varying Conditional Covariances In Tests Of Asset Pricing Models". Journal Of Financial Economics 24 (2): 289-317. doi:10.1016/0304$405 \times(89) 90049-4$.

Jegajeevan, Sujeetha. 2012. "Return Volatility And Asymmetric News Effect In Sri Lankan Stock Market". Staff Studies 40 (1): 37-57. doi:10.4038/ss.v40i1.4680.

Kahneman, Daniel, and Amos Tversky. 1979. "Prospect Theory: An Analysis Of Decision Under Risk". Econometrica 47 (2): 263-292. doi:10.2307/1914185. 
Kim, Chang-Jin, James Christopher Morley, and Charles R. Nelson. 2004. "Is There A Positive Relationship Between Stock Market Volatility And The Equity Premium?". Journal Of Money, Credit, And Banking 36 (3a): 339-360. doi:10.1353/mcb.2004.0055.

Koutmos, Gregory, Unro Lee, and Panayiotis Theodossiu. 1994. "Time-Varying Betas And Volatility Persistence In International Stock Markets". Journal Of Economics And Business46 (2): 101-112. doi:10.1016/0148-6195(94)90004-3.

Kumara, Sudath, Upananda Wita Arachchilage, and Salah Uddin Rajib. 2014. "Impact Of Ethnic War On Dynamic Properties Of Stock Return In Colombo Stock Exchange Of Sri Lanka". In International Conference On Management And Economics, 218-227. Mathara: University of Ruhuna.

Lintner, John. 1965. "The Valuation Of Risk Assets And The Selection Of Risky Investments In Stock Portfolios And Capital Budgets". The Review Of Economics And Statistics 47 (1): 13-37. doi:10.2307/1924119.

Markowitz, Harry. 1952. "PORTFOLIO SELECTION*". The Journal Of Finance 7 (1): 77 91. doi:10.1111/j.1540-6261.1952.tb01525.x.

Mehra, Rajnish, and Edward C. Prescott. 1985. "The Equity Premium: A Puzzle". Journal Of Monetary Economics 15 (2): 145-161. doi:10.1016/0304-3932(85)90061-3.

Mehra, Rajnish. 2003. "The Equity Premium: Why Is It A Puzzle? (Corrected)". Financial Analysts Journal 59 (1): 54-69. doi:10.2469/faj.v59.n1.2503.

Michelfelder, Richard, and Saurin Pandya. 2005. "Volatility Of Stock Returns: Emerging And Mature Markets". Managerial Finance 31 (2): 66-86. doi:10.1108/03074350510769505. 
Nelson, Daniel B. 1991. "Conditional Heteroskedasticity In Asset Returns: A New Approach". Econometrica 59 (2): 347-370. doi:10.2307/2938260.

Poterba, James, and Lawarence H Summers. 1986. "The Persistence Of Volatility And Stock Market Fluctuations". The American Economic Review 76 (5): 1142-1151.

Rabemananjara, R., and J. M. Zakoian. 1993. "Threshold Arch Models And Asymmetries In Volatility". Journal Of Applied Econometrics 8 (1): 31-49. doi:10.1002/jae.3950080104.

Sharpe, William F. 1964. "CAPITAL ASSET PRICES: A THEORY OF MARKET EQUILIBRIUM UNDER CONDITIONS OF RISK*". The Journal Of Finance 19 (3): 425-442. doi:10.1111/j.1540-6261.1964.tb02865.x.

Statman, Meir. 2008. "What Is Behavioral Finance?". In Hand Book Of Finance, 1st ed., 7984. John Wiley and Sons, Inc.

Theodossiou, Panayiotis. 1998. "Financial Data And The Skewed Generalized T Distribution". Management Science 44 (12-part-1): 1650-1661. doi:10.1287/mnsc.44.12.1650.

Turner, Christopher M., Richard Startz, and Charles R. Nelson. 1989. "A Markov Model Of Heteroskedasticity, Risk, And Learning In The Stock Market". Journal Of Financial Economics 25 (1): 3-22. doi:10.1016/0304-405x(89)90094-9.

Veronesi, Pietro. 1999. "Stock Market Overreactions To Bad News In Good Times: A Rational Expectations Equilibrium Model". Review Of Financial Studies 12 (5): 9751007. doi:10.1093/rfs/12.5.975. 
Wang, Yuming, and Jinpeng Ma. 2014. "Excess Volatility And The Cross-Section Of Stock Returns". The North American Journal Of Economics And Finance 27: 1-16. doi:10.1016/j.najef.2013.10.003.

Zakoian, Jean-Michel. 1994. "Threshold Heteroskedastic Models". Journal Of Economic Dynamics And Control 18 (5): 931-955. doi:10.1016/0165-1889(94)90039-6. 